\title{
Endothelin-Induced Response of the Phosphatidylinositol Cycle in Cultured Cardiomyocytes Exposed to Substrate-Free Hypoxia-Reoxygenation ${ }^{a}$
}

\author{
HAN A. A. VAN HEUGTEN, \\ KAREL BEZSTAROSTI, AND JOS M. J. LAMERS \\ Department of Biochemistry \\ Cardiovascular Research Institute COEUR \\ Faculty of Medicine and Health Sciences \\ Erasmus University Rotterdam \\ P.O. Box 1738 \\ 3000 DR Rotterdam, The Netherlands
}

\section{INTRODUCTION}

Endothelin-1 (ET-1), an endothelium-derived peptide, has a potent and sustained vasoconstrictor effect. ${ }^{1}$ ET-1 also has both positive inotropic and chronotropic effects on the heart ${ }^{2}$ and was reported to induce cardiac hypertrophy. ${ }^{3}$ The release of ET-1 is increased during hypoxia and myocardial infarction leads to increased plasma levels of ET-1.4 Moreover, hypoxia increases the number of myocardial ET-l binding sites ${ }^{5}$ as well as $\alpha_{1}$-adrenergic receptors, the latter accompanied by an increase in phospholipase C (PLC) activity in response to receptor stimulation. ${ }^{6,7}$ The signaling pathway activated by ET-1 also involves activation of $\mathrm{PLC}^{8,9}$ resulting in inositol 1,4,5-trisphosphate $\left(\mathrm{I}(1,4,5) \mathrm{P}_{3}\right)$-induced $\mathrm{Ca}^{2+}$ mobilization and protein kinase $\mathrm{C}$ (PKC) activation. ${ }^{10}$ Activation of $\mathrm{PKC}$ was shown to aggravate hypoxic myocardial injury presumably by stimulation of $\mathrm{Na}^{+} / \mathrm{H}^{+}$exchange leading to $\mathrm{Ca}^{2+}$ overload by $\mathrm{Na}^{+} / \mathrm{Ca}^{2+}$ exchange." Another acute effect of activation by ET-l is enhanced $\mathrm{Ca}^{2+}$ entry through the T-type $\mathrm{Ca}^{2+}$ channels. ${ }^{12}$

The possibility that PLC activation, through increased ET-l and receptor levels during hypoxia, leads to increased hypoxia-reoxygenation injury prompted us to investigate the activity of PLC in cultured cardiomyocytes after ET-1 stimulation during normoxia and glucose-free hypoxia-reoxygenation.

$a$ This work was supported by Grant 89.221 from the Netherland Heart Foundation. 


\section{METHODS}

\section{Cell Culture}

Primary cultures of neonatal ventricular myocytes were prepared from 1-2 day-old Wistar rats as described before. 9

\section{Analysis of Water-Soluble Inositol Phospbates}

Cardiomyocytes, 4 days after plating, were labeled with $2 \mu \mathrm{Ci}$ myo- $\left[2-{ }^{3} \mathrm{H}\right]$ inositol $/ \mathrm{ml}$ for $48 \mathrm{~h}$. Before performing the experiments, myocytes were washed with incubation buffer (130 mM NaCl; $4.7 \mathrm{mM} \mathrm{KCl} ; 1.3 \mathrm{mM} \mathrm{CaCl}_{2} ; 0.44 \mathrm{mM} \mathrm{NaH}_{2} \mathrm{PO}_{4} ; 1.1 \mathrm{mM}$

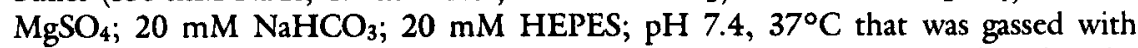
either $95 \%$ air $/ 5 \% \mathrm{CO}_{2}$ or $95 \% \mathrm{~N}_{2} / 5 \% \mathrm{CO}_{2}$ ). Thereafter, cells were incubated as described in TABLES 1 and 2 . Incubations were terminated by washing the cells followed by extraction with $4 \%$ perchloric acid and $\mathrm{CH}_{3} \mathrm{OH}: \mathrm{HCl}(100: 1 \mathrm{vol} / \mathrm{vol})$, respectively. Inositol phosphates $\left(\mathrm{IP}_{n}\right)$ were quantified by chromatography on Dowex $A G \mathrm{G} 1-\mathrm{X} 8$ as described before. ${ }^{9}$ The total of cellular $\left[{ }^{3} \mathrm{H}\right]$ inositol was defined as the sum of watersoluble inositol-containing products together with inositol lipids.

\section{RESULTS AND DISCUSSION}

As previously shown ${ }^{9}$ exposure of cardiac myocytes to ET-1 $\left(10^{-8} \mathrm{M}\right)$ results in activation of PLC. Exposure of the cells to ET-1 for only $15 \mathrm{~min}$ led to persistent stimulation of $\mathrm{IP}_{\mathrm{n}}$ production, which declined to a low level after $4 \mathrm{~h}$ (TABLE 1), still above unstimulated cells. The decline was not caused by deteriomation of cell viability as maximal stimulatability remained high over this period (TABLE 1). Not only was the

TABLE 1. Long-Lasting but Desensitized Activation of PLC after Short (15 min) Exposure of Cardiomyocytes to ET-1

\begin{tabular}{|c|c|c|c|}
\hline \multicolumn{2}{|c|}{ Addition During } & \multirow{2}{*}{\multicolumn{2}{|c|}{$\begin{array}{c}{\left[{ }^{3} \mathrm{H}\right] \mathrm{IP}_{\mathrm{n}} \text { Level }} \\
\text { (\% of cellular }\left[{ }^{3} \mathrm{H}\right] \text { inositol) }\end{array}$}} \\
\hline \multirow{2}{*}{$\begin{array}{l}\text { Preincubation } \\
0-15 \text { min }\end{array}$} & \multirow{2}{*}{$\begin{array}{c}\text { Incubation } \\
15-270 \mathrm{~min}\end{array}$} & & \\
\hline & & $30-60 \mathrm{~min}$ & $240-270 \mathrm{~min}$ \\
\hline Buffer & ET-1 & $25.6 \pm 6.9$ & $34.9 \pm 0.2$ \\
\hline ET-1 & Buffer & $13.0 \pm 3.8$ & $2.6 \pm 0.3$ \\
\hline ET-l & ET-1 & $19.9 \pm 7.9$ & $11.8 \pm 0.3$ \\
\hline
\end{tabular}

Cardiomyocytes, prelabeled with myo- $[2-3 \mathrm{H}]$ inositol, were preincubated with buffer or with ET-1 $\left(10^{-8} \mathrm{M}\right)$ for $15 \mathrm{~min}$ in the absence of $\mathrm{Li}^{+}$followed by extensive washing of the cells. At different intervals after the onset of this initial incubation cells were challenged with $\mathrm{LiCl}(10 \mathrm{mM})$ in the absence or presence of ET-l $\left(10^{-8} \mathrm{M}\right)$. Incubation in the presence of $\mathrm{Li}^{+}$was always for $30 \mathrm{~min}$. After incubation, the cells were extracted and $\left[{ }^{3} \mathrm{H}\right] \mathrm{IP}_{\mathfrak{n}}$ was quantified. Further details are described in Materials and Methods. Results are mean \pm range/2 for two experiments. Note that the presented data are already corrected for unstimulated $\left[{ }^{3} \mathrm{H}\right] \mathrm{IP}$ levels $(4.23 \pm 0.48)$. 
TABLE 2. Partial Inhibition of ET-1 Induced IP $n$ Accumulation by Hypoxia but not by Reoxygenation

\begin{tabular}{lccccc}
\hline & \multicolumn{3}{c}{$\left[{ }^{3} \mathrm{H}\right] \mathrm{IP}_{\mathrm{n}}$ Level $\left(\%\right.$ of cellular $\left[{ }^{3} \mathrm{H}\right]$ inositol $)$} \\
\cline { 2 - 3 } & \multicolumn{2}{c}{ Basal } & & ET-1 $\left(10^{-8} \mathrm{M}\right)$ Stimulated \\
\cline { 2 - 3 } \cline { 5 - 6 } & Normoxia & Hypoxia & & Normoxia & Hypoxia \\
\hline $30 \mathrm{~min}$ & $2.50 \pm 0.42$ & $2.71 \pm 0.38$ & & $21.55 \pm 2.65$ & $16.03 \pm 3.01$ \\
$60 \mathrm{~min}$ & $2.59 \pm 0.38$ & $2.85 \pm 0.30$ & & $21.58 \pm 3.95$ & $13.06 \pm 2.91$ \\
$90 \mathrm{~min}$ & $2.37 \pm 0.25$ & $2.82 \pm 0.23$ & & $20.39 \pm 2.71$ & $9.70 \pm 2.38^{*}$ \\
Reoxygenated & $1.60 \pm 0.13$ & $2.97 \pm 0.41^{* *}$ & & $5.54 \pm 1.49$ & $8.25 \pm 1.05$ \\
\hline
\end{tabular}

Cardiomyocytes, prelabeled with myo- $\left[2-{ }^{3} \mathrm{H}\right]$ inositol, were incubated in incubation buffer (see Methods) at $37^{\circ} \mathrm{C}$ in $95 \%$ air $/ 5 \% \mathrm{CO}_{2}$ (normoxia) or in $95 \% \mathrm{~N}_{2} / 5 \% \mathrm{CO}_{2}$ (hypoxia) for the periods indicated in the table. Then ET-1 was added to $10^{-8} \mathrm{M}$ in the presence of $10 \mathrm{mM} \mathrm{LiCl}$ and incubation proceeded under the same conditions for $15 \mathrm{~min}$. For reoxygenation, hypoxic buffer was replaced with fresh normoxic buffer and the incubation was continued for $15 \mathrm{~min}$ whereafter ET-l and $\mathrm{LiCl}$ were added as described above. To mimic the reoxygenation protocol, buffer exchange was also performed after $90 \mathrm{~min}$ of normoxia. Further details are described in Methods. Data are presented as mean $\pm S E M, n=7-10,{ }^{*} p<0.02$ and ${ }^{* *} p<0.005$ versus normoxia.

ET-1 response desensitized but the responsiveness of cells to a second dose of ET-1 was also diminished, remaining so up to $4 \mathrm{~h} .{ }^{9}$ These results show that brief exposure of cardiomyocytes to ET-l can lead to long-lasting but desensitized activation of PLC.

To evaluate the ET-l-evoked $\mathrm{IP}_{\mathrm{n}}$ production during glucose-free hypoxiareoxygenation, we established a model of cultured cardiomyocytes exposed to $95 \%$ $\mathrm{N}_{2} / 5 \% \mathrm{CO}_{2}$ for periods up to $90 \mathrm{~min}$ followed by 30 -min reoxygenation by bufferchange in $95 \%$ air $/ 5 \% \mathrm{CO}_{2}$. The severity of hypoxia-reoxygenation was characterized before by monitoring ATP depletion and lactate dehydrogenase (LDH) leakage during reoxygenation and these results (not shown) correlate nicely with earlier reports. ${ }^{13,14}$ Basal activity of PLC was not stimulated during 90-min hypoxia (TABLE 2). This contrasts with earlier data ${ }^{15}$ where phosphatidylinositol (PI), $\mathrm{PI}(4) \mathrm{P}$ and $\mathrm{PI}(4,5) \mathrm{P}_{2}$ were decreased in mass suggesting PLC activation, but $\mathrm{IP}_{\mathrm{n}}$ was not measured. Stimulatability of the cardiomyocytes with ET-1 $\left(10^{-8} \mathrm{M}\right)$ stayed relatively constant during a 90-min normoxic period (TABLE 2). However, after buffer change to mimic the reoxygenation protocol, the ET-l response was unexpectedly diminished. Hypoxia gradually decreased the stimulatability of cardiomyocytes with ET-1 to $38 \%$ after 90 min. Reoxygenation led to a slight but not significant increase in ET-1 response relative to normoxia.

These results show that ET-1 release from the coronary endothelium, as for example, induced by tissue hypoxia, ${ }^{4}$ can give long-lasting signal transduction in the myocardial cells at a low level. During the hypoxic period the ET-l-evoked response is further decreased by a decline in responsiveness of the cells. ET-l-induced increases in intracellular free $\mathrm{Ca}^{2+}$ by stimulation of $\mathrm{Na}^{+} / \mathrm{H}^{+}$exchange, opening of T-rype channels, and $\mathrm{I}(1,4,5) \mathrm{P}_{3}$-induced $\mathrm{Ca}^{2+}$ mobilization may contribute to development of $\mathrm{Ca}^{2+}$ overload, which is generally thought to be causally related to development of irreversible cell injury. 


\section{REFERENCES}

1. Yanagisawa, M., H. Kurihara, S. Kimura, Y. Tomobe, M. Kobayashi, Y. Mitsui, Y. YAZAKI, K. Goto \& T. MASAKI. 1988. Nature 332: 411-415.

2. Moravec, C. S., E. E. Reynolds, R. W. Stewart \& M. Bond. 1989. Biochem. Biophys. Res. Commun. 159: 14-18.

3. Ito, H., Y. Hirata, M. Hiroe, M. Tsuino, S. Adachi, T. Takamoto, M. Nitta, K. Taniguchi \& F. Marumo. 1991. Circ. Res. 69: 209-215.

4. Yasuda, M., M. Kohno, A. Tahara, H. Itagane, I. Toda, K. Akioka, M. Teragaki, H. OKu, K. Takeuchi \& T. Takeda. 1990. Am. Heart J. 119: 801.

5. Liv, J., R Chen, D. J. Casley \& W. G. Nayler. 1990. Am. J. Physiol. 258: H829-H835.

6. Kurz, T., K. A. Yamada, S. D. Datorke \& P. B. Corr. 1991. Eur. Heart J. 12 (suppl F): 88-98.

7. Kagiya, T., K. J. Rocha-Singh, N. Honbo \& J. S. Karliner. 1991. Cardiovasc. Res. 25: 609-616.

8. Prasad, M. R. 1991. Biochem. Biophys. Res. Commun. 174: 952-957.

9. Van Heugten, H. A. A., K. Bezstarosti, D. H. W. Dekkers \& J. M. J. Lamers. 1993. J. Mol. Cell. Cardiol. 25: 41-52.

10. Bogoyevitch, M. A., P. J. Parker \& P. H. Sugden. 1993. Circ. Res. 72: 757-767.

11. Ikeda, U. I., H. Arisaka, T. Takayasu, K. Takeda, T. Natsume \& S. Hosoda. 1988. J. Mol. Cell. Cardiol. 20: 493-500.

12. Furukawa, T., H. Ito, J. Nitta, M. Tsuino, S. Adachi, M. Hiroe, F. Marumo, T. Sawanobor \& M. Hiraoka. 1992. Circ. Res. 71: 1242-1253.

13. Vemuri, R. J. W. De Jong, J. A. J. Hegge, T. Huizer, M. Heller \& A. Pinson. 1989. Cardiovasc. Res. 23: 254-261.

14. Fantini, E., P. Athias, M. Courtois, S. Khataml, A. Grynberg \& A. Chevalier. 1990. Can. J. Physiol. Pharmacol. 68: 1148-1156.

15. Nachas, N. \& A. Pinson. 1992. FEBS Lett. 298: 301-305. 